\title{
Hacettepe Üniversitesi Bilgi ve Belge Yönetimi Anabilim Dalı Lisansüstü Tezlerinin Konu Analizi
}

\section{Topic Analysis of Graduate Theses of Hacettepe University Information Management Department}

\section{Meltem Dişli*}

$\ddot{O}_{z}$

Bu çalışmada Hacettepe Üniversitesi Bilgi ve Belge Yönetimi Anabilim Dalında 2002-2020 yılları arasında yapılan 112 lisansüstü tezin (74 yüksek lisans, 38 doktora) konusal olarak incelenmesi amaçlanmıştır. YÖK Tez Merkezi'nden elde edilen tezler konu modellemesi yöntemi kullanılarak 8 ana konu (okuma alışkanlı̆̆l, elektronik kaynaklar ve bibliyometrik çalışmalar, belge yönetimi, dijital kültürel miras ve açık erişim, kullanılabilirlik ve bilgi erişim, kullanıcı araştırmalarl, halk ve üniversite kütüphaneleri, bilgi güvenliği ve etik) altında gruplandırılmıştır. Konuların dönemlere, tez türüne ve danışmanlara göre dăğlımları incelenmiştir. Tez türüne göre konusal açıdan bir farklılık görülmemiştir. Dönemsel olarak genişleyen ve daralan konular olduğu sonucuna ulaşılmıştır. 2002-2020 yılları arasında en çok kullanıcı araştırmaları, en az ise kullanılabilirlik ve bilgi erişim konuları çalışılmıştır. Tezlerde en fazla Bülent Yılmaz, Yaşar Tonta ve Özgür Külcü'nün danışmanlık yaptığl ve danışmanların çoğunlukla belirli konulardaki tezleri yönettiği belirlenmiştir. Araştırma sonucunda bilgi paylaşımı, kültürel miras, açık erişim, dijitalleştirme, dijital insani bilimler, bilgi erişim, kullanılabilirlik, e-devlet, elektronik veri, kişisel veri, bilgi güvenliği gibi konuların daha fazla çalışılması önerilmiştir. Bu araştırmanın sonuçlarının tez konusu seçiminde öğrenci ve danışmanlara rehberlik edebileceği düşünülmektedir.

Anahtar Sözcükler: Bilgi ve Belge Yönetimi tezler, konu analizi, konu modelleme, araştırma ĕgilimleri

\begin{abstract}
In this study, it was aimed to examine 112 theses and dissertations (74 master, 38 doctorate) completed in Hacettepe University Department of Information Management between 20022020. Theses and dissertations which were obtained from Council of Higher Education Thesis Center, were grouped under 8 main topics (reading habits, electronic resources and bibliometric studies, records management, digital cultural heritage and open access, usability and information retrieval, user studies, public and university libraries, information security and ethics) by using the topic modeling method. The distribution of the topics according to the period, thesis type and supervisors were examined. There was no difference in topic matter
\end{abstract}

\footnotetext{
* Arş. Gör., Hacettepe Üniversitesi, Bilgi ve Belge Yönetimi Bölümü, Türkiye. E-posta: meltem.disli@hacettepe.edu.tr Research Assistant, Hacettepe University, Department of Information Management, Turkey.
}

Geliş Tarihi - Received: 15.10 .2020

Kabul Tarihi - Accepted: 30.12.2020 
according to the type of thesis. It was concluded that the topics have been expanding and narrowing down according to periods. Between 2002-2020, the most studied topic was user studies while the least studied ones were usability and information retrieval. In theses and dissertations, it was determined that Bülent Yllmaz, Yaşar Tonta and Özgür Külcü were the supervisors most and that the supervisors mostly advised the theses on certain topics. As a result of the research, it was suggested to conduct more studies on topics such as information sharing, cultural heritage, open access, digitization, digital humanities, information retrieval, usability, e-government, digital data, personal data, information security. It is thought that the results of this research can guide students and supervisors in choosing a thesis topic.

Keywords: Information Management theses and dissertations, topic analysis, topic modeling, research trends.

\section{Giriş}

Üniversiteler toplumsal gelişmeyi sağlayan bilimsel bilginin üretilmesinde en önemli kurumlardır. Üniversitelerin araştırma yapma ve bilimsel bilgi üretme görevlerinin büyük bir kısmı ise lisansüstü eğitim süreçlerinde gerçekleştirilen çalışmalar ile sağlanmaktadır (Alkan, 2014, s. 42). Lisansüstü eğitim bireylere kapsamlı ve nitelikli araştırmalar yapma, mesleğinde uzmanlaşma, mesleki sorunlara çözüm yolları bulma, yeni bilgiler üretebilme ve sentez yapabilme becerileri kazandırmayı amaçlamaktadır (Karaman ve Bakırc1, 2010, s. 95). Lisansüstü Eğitim ve Öğretim Yönetmeliği’ne (2016) göre yüksek lisans programlarının amacı öğrenciye bilgiye erişme, bilgiyi değerlendirme, yorumlama ve üretme becerisi kazandırmak iken doktora programlarının olayları derinlemesine inceleme, yorumlama, yeni sentezlere ulaşma, bilime yenilik getirme, yeni araştırma yöntemleri geliştirme, yeni uygulama alanı geliştirme gibi amaçları bulunmaktadır. Hem yüksek lisans hem de doktora programlarının temel amaçlarından olan bilim üretimine üniversiteler tez çalışmaları ile kaynaklık etmektedir (Benligiray, 2009, s. 169).

Tezler, üniversitelerde öğrencilerin bilimsel bir araştırmanın sonucu olarak belirli biçimsel özelliklere uygun bir şekilde hazırladıkları ve genellikle derece almak için bir sınav kurulu önünde savundukları bilimsel yapıtlardır (Türkiye Bilimler Akademisi [TÜBA], 2020). Belirli bir alanın sorunlarını derinlemesine irdeleyen, çözüm önerileri getiren, alana yenilik kazandıran tez çalışmaları son derece önemli çalışmalardır. Bir alanda yapılan tez çalışmalarının analiz edilmesi ve araştırma eğilimlerinin belirlenmesi de bir o kadar önemlidir.

Bu araştırmada Hacettepe Üniversitesi Bilgi ve Belge Yönetimi (HÜBBY) Anabilim Dalında yapılan tezlerin konusal olarak incelenmesi ve alanda gerçekleştirilen tezlerin eğilimlerinin belirlenmesi hedeflenmiştir. Araştırma kapsamında konu modellemesi yapılmış ve belirlenen konularda geçen kelime sıklıklarının analizinde n-gram tekniği kullanılmıştır. Bu doğrultuda araştırmada tezlerin konu dağılımlarının belirlenmesi ve dönemsel olarak eğilimlerin ortaya çıkarılması amaçlanmıştır.

\section{Hacettepe Üniversitesi Bilgi ve Belge Yönetimi Anabilim Dalı}

HÜBBY eğitim vermeye 1972 yılında "Kütüphanecilik ve Dokümantasyon Enstitüsü” adı altında lisansüstü düzeyde başlamıştır (Çakın, 2005, s. 13). Lisans düzeyinde eğitime 1974'te başlayan Hacettepe Üniversitesi Kütüphanecilik Bölümü, 1993 yılında "Kütüphanecilik", 
“Arşivcilik" ve "Dokümantasyon-Enformasyon" olmak üzere üç anabilim dalı altında eğitim vermeye devam etmiştir (Çakın, 2012, s. 270). Teknolojik gelişmeler anabilim dallarını birbirlerine yakınlaştırmış, verilen eğitimde de bilgi merkezi türlerinin farklılıklarından çok bilgi olgusuna odaklanmayı gerektirmiştir. 2002 yılında üç anabilim dalı "Bilgi ve Belge Yönetimi" adı altında tekrardan birleştirilmiş, dersler ve içerikleri güncellenmiştir. Lisans programı değiştirildikten sonra 2005 yılında lisansüstü programlar da değişikliğe uğramış ve kütüphanecilik ağırlıklı derslerin yer aldığı lisansüstü programlar yerini üç anabilim dalının ve bilgi teknolojilerinin kapsandığı ders programlarına bırakmıştır (Çakın, 2007, s. 22). 2011 yılında teknolojik gelişmelere ayak uydurmak amacıyla lisans düzeyi ders programında değişiklik yapılmış (Çakın, 2012, s. 273), lisansüstü düzeyde ise büyük bir değişim olmamıştır.

HÜBBY öğretim elemanları her zaman değişime ayak uydurarak verilen eğitimin güncel kalması için çabalamıştır (Önal ve Dişli, 2017, s. 159). Bu bağlamda ders programları pek çok kez güncellenmiştir. 2002 yılında anabilim dallarının "Bilgi ve Belge Yönetimi Bölümü” adı altında birleştirilmesi ise bölümde verilen eğitim, gerçekleştirilen araştırmalar ve mezunların iş imkânları gibi çeşitli açılardan en köklü değişim olmuştur. Kuşkusuz bu değişim, öğretim elemanlarının ve öğrencilerin bakış açısını da değiştirmiş, araştırma eğilimlerinde etkili olmuştur.

\section{İlgili Çalışmalar}

Literatürde kütüphane ve bilgi bilimi alanındaki tezlere yönelik araştırmaların atıf analizi ve içerik analizi üzerine yoğunlaştığı görülmektedir. Yılmaz'ın (1997, s. 197-198) çalışması bu çalışma ile doğrudan ilişkili olmasıyla dikkat çekmektedir. Yılmaz çalışmasında 1974-1997 yılları arasında yapılan Hacettepe Üniversitesi Kütüphanecilik Bölümü lisansüstü tezlerini niceliksel ve konusal açıdan incelemiştir. Araştırmada tezlerin en çok halk kütüphaneleri ve üniversite kütüphaneleri gibi belirli bir kütüphane türü ile ilgili konularda yürütüldüğü ve bazı konularda çok az sayıda tez yapıldığı saptanmıştır. Al ve Tonta (2004, s. 19-20) ise Hacettepe Üniversitesi Kütüphanecilik Bölümü tezlerinin atıf analizini yapmıştır. Tezlerde en çok kitaplara atıf yapıldığg, dergilerden en çok Türk Kütüphaneciliği’nin atıf aldığg, doktora tezlerindeki atıf sayısının yüksek lisans tezlerinden daha fazla olduğu ve yüksek lisans tezlerindeki atıf yapılan kaynakların doktora tezlerinde atıf yapılan kaynaklardan daha genç olduğu sonuçlarına ulaşılmıştır. Başka bir çalışmada Tonta ve Al (2006, s. 287), Hacettepe Üniversitesi Kütüphanecilik Bölümünde 1974 ve 2002 yılları arasında tamamlanan 100 tezin bibliyometrik özelliklerini analiz etmiş, tezlerde sırasıyla en çok üniversite kütüphaneleri, halk kütüphaneleri, kullanıcı araştırmaları, çocuk kitapları ve okul kütüphaneleri konularının çalışıldığını ortaya çıkarmışlardır. 2012 yılında yapılan HÜBBY tezlerinin atıf analizi çalışmasında tezlerde en çok betimleme yöntemi kullanıldığı, üniversite kütüphaneleri, halk kütüphaneleri, okuma alışkanlığı ve kullanıcı araştırmaları konularının çalışıldığı, 2004'teki çalışmaya benzer olarak en fazla kitaplara ve dergilerden Türk Kütüphaneciliği'ne atıf yapıldığı, en çok Tonta'nın atıf aldığı gibi sonuçlara ulaşılmıştır (Al ve Doğan, 2012).

Altınörs (1983, s. 66), Türkiye'de Kütüphanecilik Bilim Dalında 1958-1982 yılları arasında yapılan tezlerde kullanılan araştırma yöntemlerini incelemiş, en fazla betimleme yöntemi kullanıldığı sonucuna ulaşmıştır. Kurbanoğlu (1996, s. 357), literatüre dayalı yapmış olduğu çalışmasında kütüphane ve bilgi bilimi alanlarında yapılan tezlerin araştırma 
yöntemlerini ayrı ayrı incelemiş ve her iki disiplinde de tezlerde en çok betimleme yöntemi kullanıldığını; kütüphane biliminde ikinci sırada tarihsel yöntem kullanılırken, bilgi biliminde deneysel yöntemin kullanıldığını saptamıştır. Bir başka çalışmada ise Türkiye'deki 1958-2002 yılları arasında kullanıcı araştırmaları konusunda gerçekleştirilen tezler araştırma yöntemi, örneklem ve konu bağlamında incelenmiştir (Uçak, 2004, s. 123). İstanbul Üniversitesi Bilgi ve Belge Yönetimi Bölümü'nde 1967-2008 yılları arasında gerçekleştirilmiş tezlerin içerik analizinin yapıldığı bir çalışmada, tezlerin çalışılan konu, yöntem ve örgüt türü açısından belirli alanlarda yoğunlaştığı sonucuna ulaşılmıştır (Kayaoğlu, 2009, s. 557). Düzyol (2011), Türkiye'deki kütüphane ve bilgi bilimi alanlarında 1974-2009 y1lları arasında yapılan tez ve makaleleri yazar ortak atıf analizi yöntemiyle incelemiş; çoğunlukla halk kütüphaneleri, üniversite kütüphaneleri ve elektronik bilgi hizmetleri konularının çalışıldığı, yüksek atıf alan yazar sayısının az olduğu, atıfların genellikle yerli yazarlara ait olduğu ve genellikle tezlerden geldiği gibi sonuçlara ulaşmıştır. Ankara Üniversitesi Bilgi ve Belge Yönetimi tezlerinin bibliyometrik analizinin yapıldığı bir çalışmada yabancı dildeki dergilerden daha çok yararlanıldığı, Türkçe dergilerden ise en çok Türk Kütüphaneciliği'ne atıf verildiği sonuçlarına ulaşılmıştır (Bayram ve Zan, 2014, s. 234). İstanbul Üniversitesi Bilgi ve Belge Yönetimi Bölümü'nde 1967-2015 yılları arasında bitirilmiş tezlerin atıf analizinin yapıldı̆̆ı çalışmada da Türk Kütüphaneciliği'nin en sık atıf alan süreli yayın olduğu sonucuna ulaşılmıştır (Canata ve diğerleri, 2017, s. 40).

Uluslararası literatür incelendiğinde kütüphane ve bilgi bilimi alanındaki tezler ile ilgili olarak araştırma yöntemlerinin belirlenmesi, konusal incelemeler ve atıf analizleri yapıldığ görülmektedir. Blake (1994) çalışmasında Dissertations Abstracts International'da kütüphane ve bilgi bilim alanlarındaki tezlerin özetlerini analiz ederek tezlerdeki araştırma yöntemlerini incelemiştir. Yeap ve Kaur (2008) ise Malaya Üniversitesi kütüphane ve bilgi bilim alanında 2000-2005 yılları arasında yapılan yüksek lisans tezlerinin atıf analizini yapmıştır. Çalışma en fazla kitap ve dergilere atıf verildiğini, elektronik kaynak kullanımında sürekli artış olduğu ve genellikle tek yazarlı yayınların tercih edildiğini göstermiştir. 2013 yılında gerçekleştirilen bir araştırmada Çin'deki kütüphane ve bilgi bilimi alanındaki 1994-2011 yılları arasında yapılan doktora tezlerinin entelektüel yapısı kümeleme ve sosyal ağ analizleri ile haritalandırılmıştır. Çalışma sonucunda Çin'de kütüphane ve bilgi bilimi alanında doktora eğitimi veren en önemli üniversitenin Wuhan Üniversitesi olduğu sonucuna ulaşılmıştır. Araştırma, tezlerde en çok bilgi kaynakları, ontoloji, semantik web, semantik arama, e-devlet, bilgi yönetimi, bilgi paylaşımı, bilginin organizasyonu, bilgi hizmeti, bilgi gereksinimi ve dijital kütüphane gibi konulara odaklanıldığını ortaya çıkarmıştır (Zong ve diğerleri, 2013, s. 796). Bir başka çalışmada Kuzey Amerika'da 1960-2013 yılları arasında kütüphane ve bilgi bilim alanında yapılan doktora tezlerinin konusal incelemesi yapılmış, kütüphane ve bilgi biliminin yakından ilişkili alanlar olduğu sonucuna ulaşılmıştır. Çalışmada, kütüphane ve bilgi bilimi alanlarında gerçekleştirilen doktora tezlerinde 1970'lerde kütüphane bilimine yönelik çalışmalar ağırlıktayken, 2010'larda bilgi bilimine yönelik çalışmaların ağırlık kazandığı ortaya çıkmıştır. Ayrıca çalışma tez danışmanlarının akademik geçmişinin tezlerin disiplinlerarasılığını etkilediğini göstermektedir (Shu ve diğerleri, 2016, s. 136-137). Zin'in (2017) Yadanabon Üniversitesi Kütüphane ve Bilgi Çalışmaları Bölümü yüksek lisans tezlerinin bibliyometrik analizini yaptığı çalışmasında, tezlerde en sık koleksiyon geliştirme ve bibliyometrik çalışmalar konularının yer aldığı görülmektedir. Çin'de son 20 yılda yapılan Kütüphane ve Bilgi Bilimi doktora tezlerinin 
konusal analizinin yapıldığı bir çalışmada, bilgi bilimi çalışmalarının kütüphane bilimi ve arşiv çalışmalarından daha fazla olduğu; en çok bilgi yönetimi, enformetri ve araştırma değerlendirme, kamu hizmetleri konularında çalışıldığı ve tez danışmanlarının akademik geçmişlerinin tezlerin disiplinlerarasılı̆̆ını etkilemediği sonuçlarına ulaşılmıştır (Song, Zhu ve Shu, 2020, s. 4-6).

\section{Yöntem}

Bu çalı̧̧mada HÜBBY Anabilim Dalı'nda 2002-2020 yılları arasında yapılan 112 lisansüstü tez konusal olarak incelenmiştir. Araştırma Mayıs ayında yapıldığından 2020 bahar döneminde bitirilen tezler araştırmaya dâhil edilmemiştir. Araştırma kapsamında yanıt aranan sorular şunlardır:

S1: Anabilim dalında tamamlanan tezlerde dönemsel olarak daralan ve genişleyen konular bulunmakta midır?

S2: Tez türüne göre konular arasında anlamlı bir farklılık görülmekte midir?

S3: Danışmanların konulardaki dağılımı nasıldır?

Araştırma soruları doğrultusunda araştırmanın hipotezleri "belirli konulara her dönem diğer konulardan daha fazla ağırlık verilmiştir" (H1) ve "danışmanlar belirli konular altında yoğunlaşmaktadır” (H2) şeklinde belirlenmiştir.

Çalışmada yöntem olarak metin madenciliği yöntemi kullanılmıştır. Metin madenciliği yöntemi, yapılandırılmamış metin verilerinden bilgi ve eğilimler elde etmeyi sağlayan yarı otomatik süreçleri içeren bir yöntemdir (Delen ve Crossland, 2008, s. 1707; Liew, Adhitya ve Srinivasan, 2014, s. 394). Metin madenciliği akademik yayınların konusal analizinde, araştırma eğilimleri, zayıflayan ve genişleyen araştırma konuları ve konu kategorilerinin belirlenmesinde kullanılabilmektedir (Binici, 2016, s. 12).

Çalışma üç anabilim dalının 2002 yılında Bilgi ve Belge Yönetimi Bölümü adı altında örgütlenmesinden Mayıs 2020'ye kadar yapılan 112 tezi kapsamaktadır. Tezler, YÖK Ulusal Tez Merkezi'nin detaylı tarama bölümünden üniversite olarak Hacettepe Üniversitesi, anabilim dalı olarak Bilgi ve Belge Yönetimi Anabilim Dalı seçilerek belirlenmiştir. Arama sonuçlarında 110 teze ulaşılmıştır. 1997 yılında yapılan bir tez sonuçlar içinde çıkmasına rağmen Kütüphanecilik Anabilim Dalı'nda yapıldığı için araştırmaya dâhil edilmemiştir. Ayrıca veriler Hacettepe Üniversitesi Açık Erişim Sistemi ve Türkiye Bilgi ve Belge Yönetimi Bölümleri Lisansüstü Tez Arşivi'nden de kontrol edilmiş; YÖK Ulusal Tez Merkezi'nde yer almayan 3 tez de araştırmaya dâhil edilmiştir. Tezlerin yazar adı, danışman adı, tarih, tez adı, tez türü, öz ve anahtar kelimeleri Excel'de kaydedilmiştir.

Verilerin analizinde açık kaynak kodlu bir metin analizi yazılımı olan Knime kullanılmıştır. Knime yazılımına aktarılan Excel dosyası öncelikle veri ön işleme aşamalarından geçirilmiştir. Büyük küçük harf duyarlılığından kaynaklı sorunları önlemek için ilk önce tüm metin küçük harflere dönüştürülmüsstür. Daha sonra noktalama işaretleri ve durak kelimeleri metinden kaldırılmıştır. Durak kelimeleri metinlerde çok fazla geçen ve kendi başına bir anlam ifade etmeyen kelime, bağlaç ve edatlardır (Binici, 2016, s. 23). Veri ön işlemenin son aşaması olan gövdeleme ise aynı kökten gelen kelimeleri birleştirmek, kelimelerin yalın hallerini bulmak için yapılmıştır. Gövdeleme yöntemi ile kelimelerin tekil ve çoğul hallerinde 
de normalleşme sağlanabilmektedir (Binici, 2016, s. 24). Bu çalışma kapsamında Türkçe metinler için geliştirilen bir gövdeleme algoritması olan Zemberek Stemmer kullanılmıştır.

Veri ön işleme aşamalarından sonra konu modellemesi ile tezlerin konusal analizi yapılmıştır. Konu modelleme bir koleksiyonda yer alan belgelerdeki kelimelerin istatistiksel analizlerine, kelime birlikteliklerine ve ilişkilerine dayanarak belgelerdeki konuları belirlemeyi amaçlayan bir yöntemdir (Figuerola, García Marco ve Pinto, 2017, s. 1514). Bu çalışmada en yaygın kullanılan konu modelleme algoritmalarından biri olan LDA (Latent Dirichlet Allocation/Gizli Dirichlet Ayrımı) kullanılmıştır. LDA her bir belgenin konu koleksiyonu olarak düşünülebileceği ve belgedeki her kelimenin bir konuyla ilişkilendirilebileceği fikrine dayanan bir konu modelleme türüdür (Figuerola, García Marco ve Pinto, 2017, s. 1516).

Tezler LDA aracılığıyla 8 farklı ana konuya ayrıldıktan sonra her bir konuda yer alan tezler n-gram analizine tabi tutularak bu konular içinde en çok çalışılan alt konular saptanmıştır. $\mathrm{N}$-gram analizi metindeki kelime öbekleri veya karakterlerin yan yana bulunma örüntülerini ortaya çıkarmaktadır (Binici, 2016, s. 22). Çalışma kapsamında n-gram analizinden elde edilen ikili (bi-gram) ve üçlü (tri-gram) kelime öbekleri doküman sıklıkları dikkate alınarak gösterilmiştir. Bazı konu kategorilerinde çok az tez bulunmasından kaynaklı olarak n-gram analizlerinde doküman sıklıklarının çok düşük çıkması araştırmanın sınırlılıklarındandır. Ngram analizi tamamlandıktan sonra daha önceden gövdeleme yapılan kelimeler tablolarda düzeltilerek verilmiştir. "Elde edilen”, "yer alan", "ulaşılan sonuçlar", "araştırma kapsamında" gibi her tezde sıklıkla geçen ve konusal olarak bir anlam ifade etmeyen kelimeler tablolara dâhil edilmemiştir. Ayrıca bu araştırmanın amacı araştırma yöntem ve tekniklerini belirlemek olmadığından n-gram analizlerinde çıkan yöntem ve teknikler ile ilgili kelime öbekleri çıkarılmıştır. Aynı şekilde kurum isimleri de n-gram analizlerinden çıkarılmıştır.

Son olarak her bir konuya, konuların içinde ağırlıklı olarak bulunan alt konular göz önünde bulundurularak, kapsayıcı bir etiket atanmıştır. Atanan etiketler araştırmanın daha anlaşılır bir şekilde okunmasını sağlamaktadır. Ana konular belirlendikten sonra tezlerin yılı, türü ve konuları SPSS yazılımına aktarılmıştır. SPSS aracılığıyla tezlerin konuları ile tez türü ve dönemler arasında anlamlı bir ilişki olup olmadığı ki-kare testleri ile analiz edilmiştir.

\section{Bulgular ve Yorum}

Çalışmanın bu bölümünde HÜBBY Anabilim Dalında yapılan lisansüstü tezler konusal olarak incelenmektedir. Bu kapsamda öncelikle yüksek lisans ve doktora tezlerinin yıllara göre dağılımı gösterilmektedir (Şekil 1). Konu modelleme ve n-gram analizleri kullanılarak ana ve alt konular belirlendikten sonra tezlerin konuları ile tez türü ve danışmanlar arasındaki ilişkiler değerlendirilmiştir. Bunların yanı sıra genişleyen ve daralan konuların saptanabilmesi için dönemlere göre konusal dağılım incelenmiştir. 


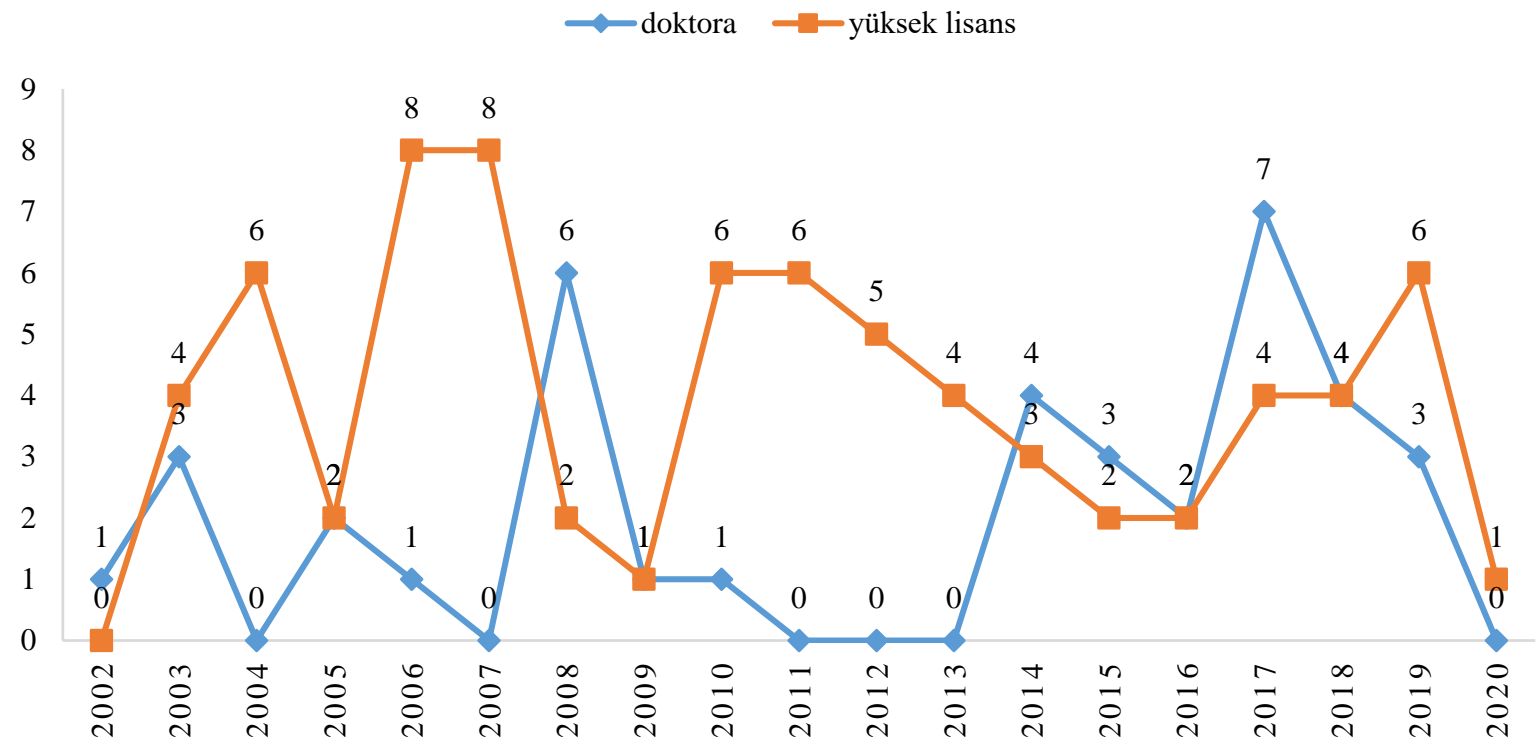

Şekil 1. Tez türlerinin yıllara göre dağılımı

Çalışma kapsamında 2002-2020 yılları arasında yapılan tezler incelenmiştir. Bu tezlerin \%66's1 (74) yüksek lisans, \%34'ü (38) doktora tezidir. Şekil 1'de de görüldüğü üzere tez türlerinin dağılımı yıllara göre farklılık göstermektedir $\left(\chi^{2}=36,522, \mathrm{p}=0,006\right)$. En fazla doktora tezi 2017 (\%18) ve 2008 (\%16) yıllarında, en fazla yüksek lisans tezi ise 2006 (\%11) ve 2007 (\%11) yıllarında tamamlanmıştır. Yüksek lisans tezlerinde 2002 yılı hariç her yıl en az 1 tez bitirilmişken, doktorada hiç tez bitirilmeyen yıl çok fazladır (6 yı1, \%33). Bu durumun yüksek lisans süresinin daha kısa olması ve yüksek lisansta daha fazla öğrenci olmasından kaynaklandığı düşünülmektedir. Doktorada hem ders döneminin hem de tez yazım sürecinin uzun olması her yıl tez bitirilmemesine sebep olabilmektedir. 2008 ve 2017 yıllarında diğer yıllara göre çok daha fazla tez bitirilmiştir. Bu durumun ise 2006 ve 2016 yıllarındaki yönetmeliklerle gelen süre değişikliklerinden kaynaklandığı düşünülmektedir.

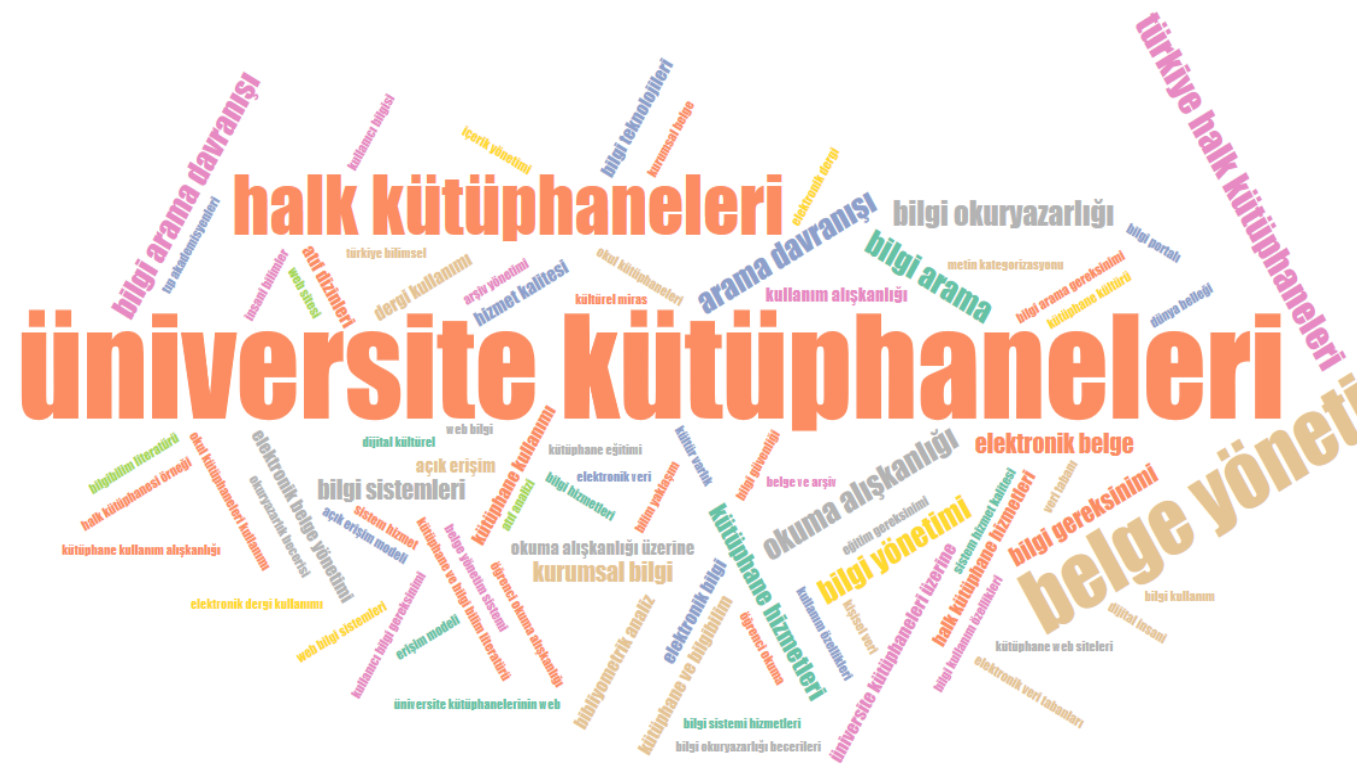

Şekil 2. Tezlerde öne çıkan konular 
Şekil 2'de Anabilim Dalı'nda yapılan tezlerin başlık, öz ve anahtar kelimeleri üzerinde uygulanan bi-gram ve tri-gram analizleri doküman sıklıkları dikkate alınarak kelime bulutu ile gösterilmiştir. En az 2 tezde geçen kelime öbekleri görselde yer almaktadır. Kelime öbeklerinin büyüklüğü tezlerde geçiş sıklıklarını göstermektedir. N-gram analizi ile elde edilen kelime bulutu tezlerde öne çıkan konular hakkında fikir verebilmektedir. Tezlerde büyük çoğunlukla üniversite kütüphaneleri ile ilgili çalışmalar yapıldığı görülmektedir. Üniversite kütüphanelerini belge yönetimi ve halk kütüphaneleri konuları takip etmektedir. Öne çıkan diğer konular bilgi okuryazarlığı, bilgi arama davranışı, okuma alışkanlığı, bilgi yönetimi, bilgi gereksinimi, bilgi sistemleri, elektronik belgeler ve kütüphane hizmetleridir. Kültürel miras, arşiv yönetimi, elektronik veri, kişisel veri, bilgi güvenliği, içerik yönetimi, dijital insani bilimler gibi konuların tezlerde belirtilen diğer konulara oranla daha az çalışıldığ görülmektedir. Tezlerdeki ana ve alt konular Tablo 1'de ayrıntılı bir biçimde yer almaktadır.

\section{Tablo 1}

Tezlerdeki ana ve alt konular

\begin{tabular}{|c|c|c|c|c|}
\hline \multirow[t]{2}{*}{ Konular } & \multicolumn{2}{|l|}{ Alt konular } & \multirow[t]{2}{*}{ Atanan etiket } & \multirow[t]{2}{*}{ Tez sayısı } \\
\hline & İkili n-gram analizi & Üçlü n-gram analizi & & \\
\hline Konu 1 & $\begin{array}{l}\text { Okuma alışkanlığı, } \\
\text { alışkanlık kazandırma, } \\
\text { kütüphane kullanımı, } \\
\text { çocuk okuma, kitap } \\
\text { okuma, okul } \\
\text { kütüphaneleri, kullanım } \\
\text { alışkanlığı, ilköğretim } \\
\text { okulları, halk } \\
\text { kütüphaneleri, kütüphane } \\
\text { hizmetleri }\end{array}$ & $\begin{array}{l}\text { Okuma alışkanlığı } \\
\text { üzerine, okuma } \\
\text { alışkanlığı kazandırma, } \\
\text { ögrenci okuma } \\
\text { alışkanlığı, okul } \\
\text { kütüphane kullanımı, } \\
\text { kütüphane kullanım } \\
\text { alışkanlığı, çocuklarda } \\
\text { okuma alışkanlığ1 }\end{array}$ & Okuma alışkanlığı & 11 \\
\hline Konu 2 & $\begin{array}{l}\text { Üniversite kütüphaneleri, } \\
\text { koleksiyon geliştirme, veri } \\
\text { tabanları, atıf sayıları, } \\
\text { kütüphane koleksiyonu, } \\
\text { kütüphane bilgi bilim, } \\
\text { bilgi bilim literatürü, } \\
\text { bilimsel iletişim, yayın } \\
\text { üretimi, politika geliştirme }\end{array}$ & $\begin{array}{l}\text { Kütüphane ve bilgi bilim } \\
\text { literatürü, atıf } \\
\text { dizinlerinde yer alan, } \\
\text { Türkiye adresli yayınlar, } \\
\text { elektronik veri tabanları, } \\
\text { elektronik dergi } \\
\text { kullanımı }\end{array}$ & $\begin{array}{l}\text { Elektronik kaynaklar ve } \\
\text { bibliyometrik çalışmalar }\end{array}$ & 15 \\
\hline Konu 3 & $\begin{array}{l}\text { Kurumsal bilgi, bilgi } \\
\text { sistemleri, elektronik } \\
\text { belge, sistem kullanımı, } \\
\text { elektronik ortam, belge } \\
\text { işleme, yasal idari, } \\
\text { kurumsal belge, bilgi } \\
\text { teknolojileri, e-devlet } \\
\text { uygulamaları }\end{array}$ & $\begin{array}{l}\text { Belge yönetim } \\
\text { uygulamaları, belge } \\
\text { yönetim sistemi, } \\
\text { elektronik belge } \\
\text { yönetimi, belge yönetim } \\
\text { programları, bilgi belge } \\
\text { sistemleri }\end{array}$ & Belge yönetimi & 18 \\
\hline Konu 4 & $\begin{array}{l}\text { Kültürel miras, miras } \\
\text { koruma, kültürel bellek, } \\
\text { bellek kurumları, miras } \\
\text { ürünleri, kültürel varlıklar, } \\
\text { miras dijital, kütüphane } \\
\text { arşiv, arşiv müze, açık } \\
\text { erişim }\end{array}$ & $\begin{array}{l}\text { Kültürel bellek } \\
\text { kurumları, kültürel } \\
\text { mirasın korunması, } \\
\text { kütüphane arşiv müze, } \\
\text { kültürel miras ürünleri, } \\
\text { dijital kültürel miras, } \\
\text { kültürel miras toplumu, } \\
\text { kültürel mirasa erişim }\end{array}$ & $\begin{array}{l}\text { Dijital kültürel miras ve } \\
\text { açık erişim }\end{array}$ & 10 \\
\hline
\end{tabular}




\begin{tabular}{|c|c|c|c|c|}
\hline Konu 5 & $\begin{array}{l}\text { Kullanıcı sorunları, verim } \\
\text { memnuniyet, görev } \\
\text { tamamlama, tıklama } \\
\text { sayıları, gerçek kullanıcı }\end{array}$ & $\begin{array}{l}\text { Kitap ve kütüphane } \\
\text { kültürü, Osmanlı } \\
\text { kitapları ve kütüphane, } \\
\text { pennant diyagram } \\
\text { yöntemi, bilgi erişim } \\
\text { literatürü, geleneksel atıf } \\
\text { analizi, web sitesi } \\
\text { kullanımı, ULAKBİM } \\
\text { web sitesi, kütüphane } \\
\text { kültür araştırması, } \\
\text { Osmanlı dönemi } \\
\text { kitapları, bilgi erişim } \\
\text { alanı }\end{array}$ & $\begin{array}{l}\text { Kullanılabilirlik ve bilgi } \\
\text { erişim }\end{array}$ & 7 \\
\hline Konu 6 & $\begin{array}{l}\text { Üniversite kütüphaneleri, } \\
\text { bilgi arama, bilgi } \\
\text { gereksinimi, bilgi erişim, } \\
\text { bilgi hizmetleri, } \\
\text { kütüphane kullanımı, } \\
\text { arama davranışı, hizmet } \\
\text { kullanım, bilgi sistemleri, } \\
\text { bilgi okuryazarlığı }\end{array}$ & $\begin{array}{l}\text { Bilgi arama davranışı, } \\
\text { kullanıcı bilgi } \\
\text { gereksinimi, üniversite } \\
\text { kütüphane kullanımı, } \\
\text { üniversite öğrenci } \\
\text { bilgisi, bilgi } \\
\text { okuryazarlık becerisi, } \\
\text { bilgi erişim konusu, } \\
\text { kütüphane web sayfası, } \\
\text { bilgi sistem hizmet, web } \\
\text { site kullanımı, hizmet } \\
\text { kalitesi boyutları, bilgi } \\
\text { hizmeti beklentisi }\end{array}$ & Kullanıcı araştırmaları & 24 \\
\hline Konu 7 & $\begin{array}{l}\text { Halk kütüphaneleri, } \\
\text { kütüphane hizmetleri, } \\
\text { kütüphane kullanımı, } \\
\text { kütüphane toplumu, } \\
\text { üniversite kütüphaneleri, } \\
\text { hizmet geliştirme }\end{array}$ & $\begin{array}{l}\text { Türkiye halk } \\
\text { kütüphaneleri, halk } \\
\text { kütüphane hizmetleri }\end{array}$ & $\begin{array}{l}\text { Halk ve üniversite } \\
\text { kütüphaneleri }\end{array}$ & 14 \\
\hline Konu 8 & $\begin{array}{l}\text { Üniversite kütüphaneleri, } \\
\text { eğitim programı, kişisel } \\
\text { veri, bilgi güvenliği, } \\
\text { korumaya yönelik, veri } \\
\text { koruma, bilgi merkezleri, } \\
\text { mesleki etik, etik ilke, } \\
\text { bilgi teknolojileri }\end{array}$ & $\begin{array}{l}\text { Kişisel verilerin } \\
\text { korunması, veri } \\
\text { korumaya ilişkin }\end{array}$ & Bilgi güvenliği ve etik & 13 \\
\hline
\end{tabular}

Tezlerin konu modellemesi ile belirlenen ana konuları, n-gram analizleri sonucu ortaya çıkan alt konular, alt konulara dayanarak atanan etiketler ve her bir konuda yer alan tez sayısı ayrıntılı bir biçimde Tablo 1'de gösterilmektedir. Konular kendi içinde n-gram analizlerine tabi tutulmuş ve doküman sıklıkları dikkate alınarak en az 3 tezde geçen en fazla 10 kelime öbeği tabloda gösterilmiştir. Konu 8'in doküman sıklıkları düşük olduğundan 2 tezde geçen kelime öbeklerine genişletilmiştir. Konu 5'te de ikili n-gram analizlerinde aynı şekilde 2 tezde geçen kelime öbekleri alınmış, üçlü n-gram analizlerinde ise cümle sıklıkları dikkate alınmıştır. Konu 6'da ise ikili n-gram analizinde çok fazla kelime öbeği olduğundan 4 tezde eşleşenlerle sınırlandırılmıştır. Diğer konu gruplarında bu şekilde genişletme veya daraltma uygulandığında sonuçlar değişmemekte, en az 3 tezde geçen kelime öbekleriyle sınırlandırılması uygun görülmektedir. Aşağıda her bir konu ve alt konuları incelenmektedir.

Tezlerin \%9,8'ini kapsayan Konu 1 okuma alışkanlığı üzerine yoğunlaşmaktadır. İkili ve üçlü n-gram analizlerine bakıldığında Konu 1'de kitap okuma alışkanlığı kazandırma, okul ve 
halk kütüphaneleri, öğrenci ve çocukların okuma alışkanlığı kazanması ve kütüphane kullanım alışkanlığı kazanılması ile ilgili çalışmaların yer aldığı görülmektedir. Konu 1'e okuma alışkanlığı etiketi atanmıştır. Elektronik kaynaklar ve bibliyometrik çalışmalar etiketi atanan Konu 2, tezlerin \%13,4'ünü oluşturmaktadır. Burada üniversite kütüphanelerinde koleksiyon geliştirme, elektronik veri tabanları, elektronik dergi kullanımı ile ilgili çalışmaların yanı sıra kütüphane ve bilgi bilim literatüründe atıf analizi ve bilimsel iletişim konulu çalışmalar yer almaktadır. Kurumsal belge, elektronik belge, e-devlet uygulamaları, kurumsal bilgi sistemleri ve elektronik belge yönetim sistemleri ile ilgili tezlerin bulunduğu Konu 3, en fazla çalışılan ikinci $(\% 16,1)$ ana konudur. Bu konuya belge yönetimi etiketi atanmıştır. Tezlerin \%8,9'unu oluşturan Konu 4; kültürel bellek kurumları, kütüphane, arşiv ve müzeler, kültürel mirasın korunması ve dijitalleştirilmesi, dijital kültürel miras ve açık erişim konularını içermektedir. Konu 4'e dijital kültürel miras ve açık erişim etiketi atanmıştır. Tezlerde en az çalışılan ana konu, 5. konu $(\% 6,3)$ olarak karşımıza çıkmaktadır. Konu 5 altında Osmanlı döneminde kitap ve kütüphane kültürü, kullanılabilirlik, e-öğrenme ve bilgi erişim konularının çalışıldığ görülmektedir. Bu konu altında çalışılan tezlerin ilk bakışta birbirlerinden çok farklı olduğu görülse de tezler ayrı ayrı incelendiğinde, mevcut literatürden bilgi çıkarımı ve web sitelerinin kullanılabilirliği ile ilgili olmak üzere iki konu altında toplandıkları anlaşılmaktadır. Bu konuya kullanılabilirlik ve bilgi erişim etiketinin atanması uygun görülmüştür. Tezlerde en çok çalışılan ana konu ise altıncı konudur $(\% 21,4)$. Konu 6, ağırlıklı olarak üniversite kütüphanelerinde bilgi hizmetleri ve hizmet kalitesi ile üniversite öğrencilerinin bilgi arama davranışları, bilgi gereksinimleri, bilgi okuryazarlığı becerileri, bilgiye erişim sorunları ve beklentileri konularını içermektedir. Konu 6 için kullanıcı araştırmaları etiketi atanmıştır. Halk ve üniversite kütüphaneleri etiketi atanan Konu 7 ise tezlerin \%12,5'ini kapsamaktadır. Konu 7'de çoğunlukla halk kütüphaneleri ile ilgili çalışmalar yer almaktadır. Kütüphanelerde hizmet geliştirme ve kütüphane kullanımı konuları öne çıkmaktadır. Halk kütüphaneleri ile ilgili yapılan çalışmaların yanı sıra üniversite kütüphanelerinde pazarlama, halkla ilişkiler, personelin iş doyumu gibi konularda çalışmalar bulunmaktadır. Tezlerin \%11,6'sını oluşturan Konu 8, üniversite kütüphanelerinde kişisel verilerin korunmas1, bilgi güvenliği ve üniversitelerde hassas veri, intihal ve mesleki etik konularını kapsamaktadır. Bu konuya ise bilgi güvenliği ve etik etiketi atanmıştır. Her biri için etiket atanan konuların, Şekil 3 'te tez türlerine göre dağılımları gösterilmektedir.

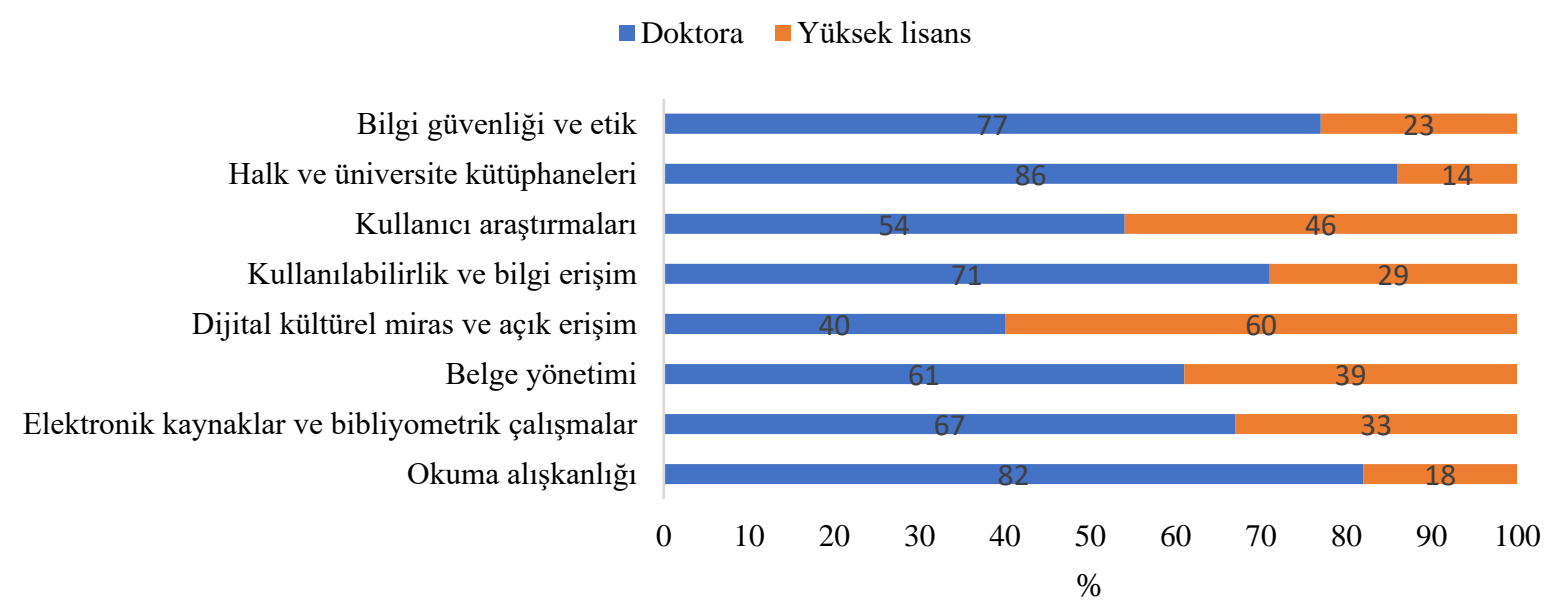

Şekil 3. Konuların tez türüne göre dağılımı 
Şekil 3, tezlerde yer alan ana konuların tez türlerine göre dağılımını göstermektedir. Dijital kültürel miras ve açık erişim konusunda yüksek lisansta; diğer konularda ise doktorada daha yüksek oranda tez bitirilmiştir. Kullanıcı araştırmaları konusunda doktorada da yüksek lisansta da birbirine yakın oranlarda tez bitirildiği görülmektedir. Ancak konuların tez türüne göre istatistiksel açıdan anlamlı bir farklılık göstermediği ortaya çıkmıştı $\left(\chi^{2}=9,148, \mathrm{p}=0,242\right)$.

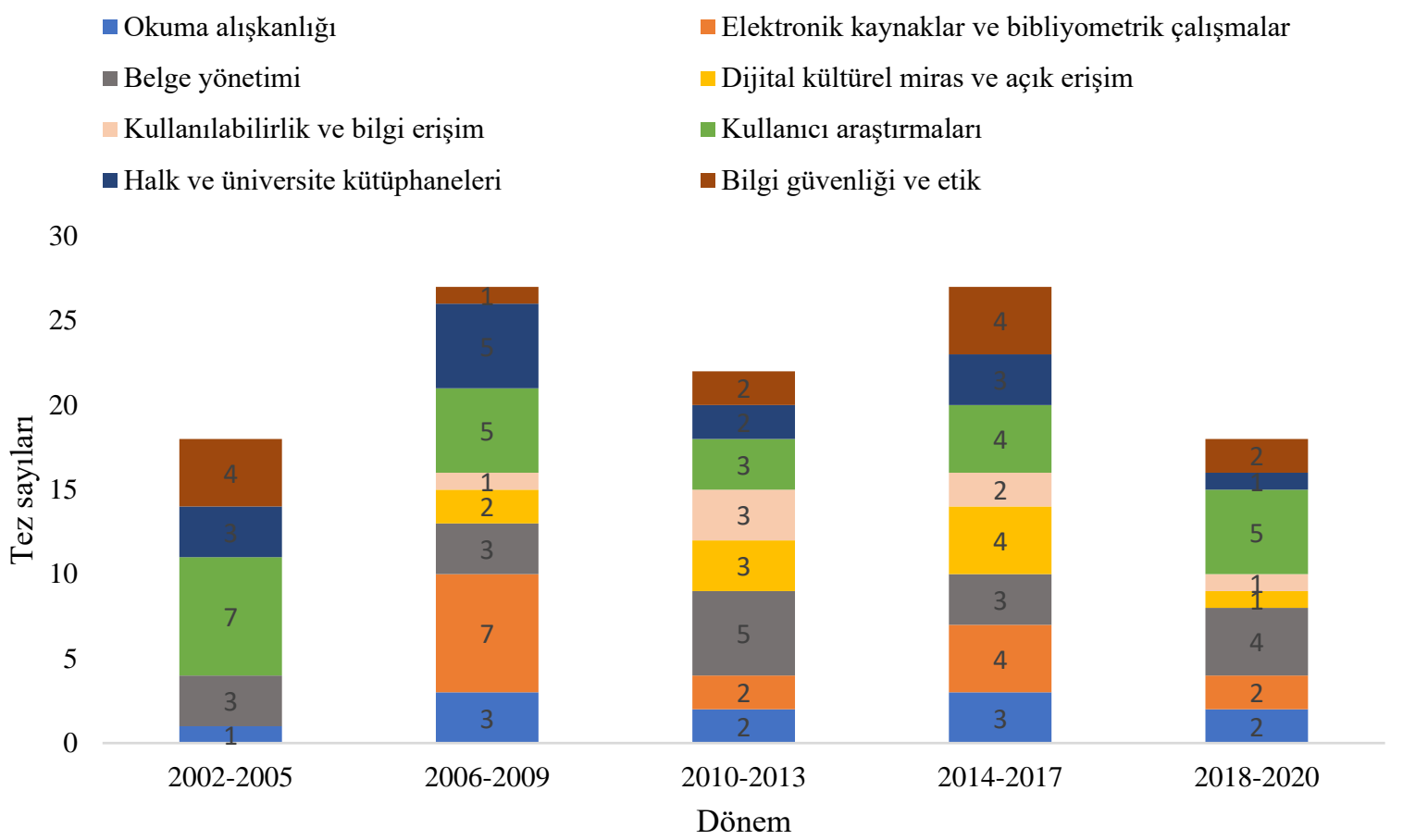

Şekil 4. Dönemlere göre tezlerin konu dağılımı

Dönemlere göre konusal dağılım, istatistiksel açıdan anlamlı bir farklılık göstermemektedir $\left(\chi^{2}=24,935, \mathrm{p}=0,631\right)$. Farkl1lıklar büyük olmasa da dönemsel olarak daralan veya genişleyen konular olduğu Şekil 4'te göze çarpmaktadır. Bu bağlamda belirli konuların her dönem diğer konulara göre daha fazla çalışıldığ yönündeki hipotez (H1) kabul edilmemiştir. Şekil 4'te de görüldüğü gibi okuma alışkanlığı, belge yönetimi, kullanıcı araştırmaları, halk ve üniversite kütüphaneleri, bilgi güvenliği ve etik konuları her dönem çalışılmıştır. Elektronik kaynaklar ve bibliyometrik çalışmalar, dijital kültürel miras ve açık erişim, kullanılabilirlik ve bilgi erişim konuları 2006-2009 yıllarında çalışılmaya başlanan konulardır. 2014-2017 dönemi en fazla tez bitirilen dönem olmakla birlikte her konunun hemen hemen eşit sayıda çalışıldığı görülmektedir. Son dönemde halk ve üniversite kütüphaneleri, dijital kültürel miras ve açık erişim, elektronik kaynaklar ve bibliyometrik çalışmalar konularında önceki dönemlere göre daha az tez bitirilmiştir. Konuların danışmanlara göre dağıılımı Şekil 5'te gösterilmektedir. 


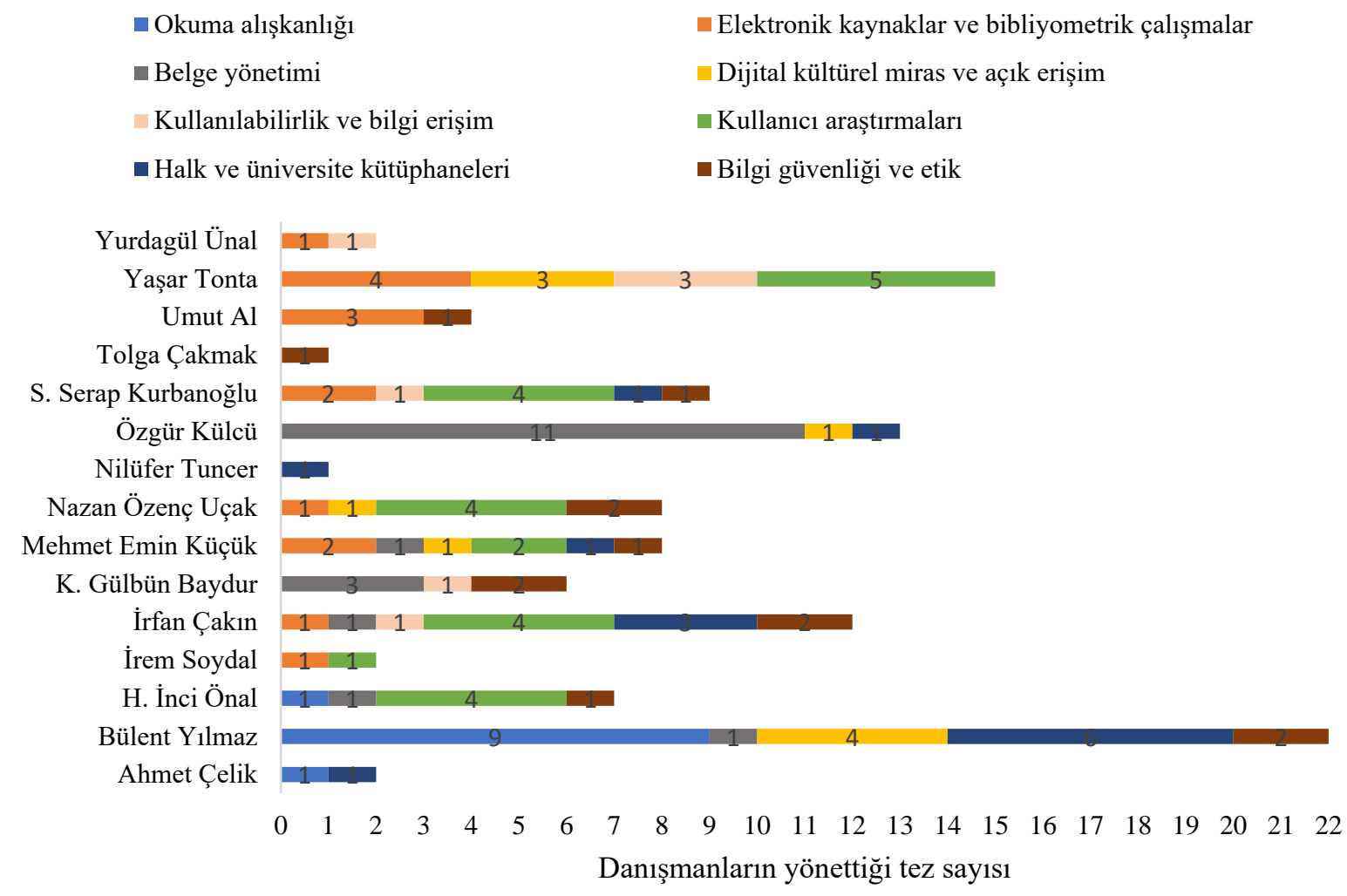

Şekil 5. Danışmanlara göre tezlerin konu dağılımı

Şekil 5 'te konuların tez danışmanlarına göre dağılımları görülmektedir. 2002-2020 yılları arasında yapılan tezlerin \%20'si (22 tez) Bülent Yılmaz'ın danışmanlığında tamamlanmıştır. Bunu Yaşar Tonta'nın (15, \%13) ve Özgür Külcü'nün (13, \%12) danışmanlığını yürüttüğü tezler takip etmektedir. Bülent Yılmaz'ın danışmanlığında yapılan tezlerin \%41'i (9) okuma alışkanlığı konusundadır. Bu tezler okuma alışkanlığı konusunda yapılan tezlerin \%82'sini oluşturmaktadır. Özgür Külcü'nün ise ağırlıklı olarak belge yönetimi etiketi altında yer alan tezlere $(11, \% 85)$ danışmanlık yaptığı görülmektedir. Burada yer alan tezlerin \%61'inin danışmanlığı Özgür Külcü tarafından yapılmıştır. Yaşar Tonta'nın ise belirli bir konuda yoğunlaşmadığı görülmektedir. Yaşar Tonta'nın danışmanlığını yürüttüğü tezler elektronik kaynaklar ve bibliyometrik çalışmalar, dijital kültürel miras ve açık erişim, kullanılabilirlik ve bilgi erişim ile kullanıcı araştırmaları konularındadır. Yürüttüğü tezler en fazla konuya dağılan danışmanlar İrfan Çakın (6 konu) ve Mehmet Emin Küçük'tür (6 konu). İrfan Çakın'ın okuma alışkanlığı ile dijital kültürel miras ve açık erişim konularında; Mehmet Emin Küçük'ün ise okuma alışkanlığı ile kullanılabilirlik ve bilgi erişim konularında yürüttüğü tez bulunmamaktadır. İnci Önal, Nazan Uçak ve Serap Kurbanoğlu'nun ağırlıklı olarak kullanıcı araştırmaları konusundaki tezlere danışmanlık yaptığı görülmektedir. Umut Al ise çoğunlukla (\%75) elektronik kaynaklar ve bibliyometrik çalışmalar konularındaki tezlere danışmanlık yapmıştır. Öğretim üyelerinin genel olarak belirli konular üzerinde danışmanlık yaptıkları saptanmış, araştırmanın danışmanların belirli konular altında yoğunlaştığına yönelik hipotezi (H2) kabul edilmiştir. 


\section{Tartışma}

Araştırmanın bulguları incelendiğinde tezlerde önceki çalışmalara (Yılmaz, 1997; Tonta ve Al, 2006; Düzyol, 2011; Al ve Doğan, 2012) benzer olarak en çok çalış1lan konuların üniversite ve halk kütüphaneleri olduğu belirlenmiştir. Konu kategorilerine göre değerlendirildiğinde ise tezlerde kullanıcı araştırmaları etiketi altında bulunan konuların diğerlerine göre çok fazla çalışıldığı görülmektedir. Bu bulgu çalışmanın sonuçlarının Al ve Doğan'ın (2012) çalışmaları ile tutarlı olduğunu göstermektedir.

Kayaoğlu'nun (2009) çalışmasında kütüphane ve bilgi biliminin analizi ile bilimsel ve mesleki iletişim konularının uzun yıllardır çalışılmadığı ortaya çıkmıştır. İstanbul Üniversitesi'nin aksine Hacettepe Üniversitesi'nde bu konular oldukça fazla çalışılmıştır. Çalışmamızda bu konuların elektronik kaynaklar ve bibliyometrik çalışmalar etiketi atanan Konu 2 altında yer aldığı ve en çok çalışılan üçüncü ana konu olduğu görülmektedir. Bibliyometrik çalışmaların çok çalışılması Zin (2017) ile Song ve diğerlerinin (2020) çalışmalarının sonuçlarına benzerdir. Çin'deki başka bir çalışmada ise tezlerde en fazla bilgi kaynakları, ontoloji, semantik web, semantik arama, e-devlet, bilgi yönetimi, bilgi paylaşımı, bilginin organizasyonu, bilgi hizmeti, bilgi gereksinimi ve dijital kütüphane konularının çalışıldığı belirlenmiştir (Zong ve diğerleri, 2013, s. 796). Bu çalışmanın bulgularına göre ise HÜBBY'de, bahsi geçen konuların bir kısmını içine alan "dijital kültürel miras ve açık erişim" ile "kullanılabilirlik ve bilgi erişim” etiketli konuların az çalışıldığı görülmektedir. Konu kategorilerine ayırmadan bakıldığında ise genel olarak arşiv yönetimi, elektronik veri, kişisel veri, bilgi güvenliği, içerik yönetimi, dijital insani bilimler gibi konuların az çalışıldığı ortaya çıkmıştır.

Araştırmanın ilk araştırma sorusu (S1) kapsamında konuların dönemlere göre dağılımı incelenmiştir. Dönemlere göre konusal olarak anlamlı bir farklılık olmadığı ancak her dönem aynı konular üzerine yüksek oranlarda tez bitirilmediği, dönemsel olarak daralan ve genişleyen konular olduğu ortaya çıkmıştır. İkinci araştırma sorusu (S2) doğrultusunda ise tez türüne göre konusal bir farklılık olup olmadığı değerlendirilmiştir. Tez türüne göre konu dağılımında anlamlı bir farklılık bulunmasa da tezlerin büyük çoğunluğunu oluşturan yüksek lisans tezlerinde dijital kültürel miras ve açık erişim konularında doktoradan daha yüksek oranda tez bitirildiği, diğer konularda ise doktorada daha yüksek oranlarda tez bitirildiği belirlenmiştir. Son araştırma sorusu (S3) kapsamında elde edilen bulgulara göre Bülent Yılmaz en fazla okuma alışkanlığı, Özgür Külcü belge yönetimi, Umut Al elektronik kaynaklar ve bibliyometrik çalışmalar, H. İnci Önal kullanıcı araştırmaları konularında yapılan tezlerin danışmanlığını yürütmüştür. Nazan Özenç Uçak ve S. Serap Kurbanoğlu da daha yoğun olarak kullanıcı araştırmaları konularındaki tezleri yönetmiştir. Yaşar Tonta'nın dört konu kategorisinde de hemen hemen eşit sayıda tez yönettiği görülmektedir. En fazla konuda danışmanlık yapan danışmanlar ise İrfan Çakın ve Mehmet Emin Küçük’tür.

\section{Sonuç ve Öneriler}

Belirli bir alandaki tezlerin araştırma eğilimlerinin belirlenmesi alandaki diğer çalışmalar için de bir 1şık tutmaktadır. Bu çalışmada Hacettepe Üniversitesi Bilgi ve Belge Yönetimi Anabilim Dalında tamamlanan lisansüstü tezler metin madenciliği yöntemleri kullanılarak konusal olarak incelenmiştir. Tezler 8 ana konu altında toplanmıştır. Ana konularda gerçekleştirilen n-gram 
analizleri sonucunda alt konular belirlenmiş, her bir ana konuya alt konuları kapsayacak nitelikte bir etiket atanmıştır. Tezler okuma alışkanlığı, elektronik kaynaklar ve bibliyometrik çalışmalar, belge yönetimi, dijital kültürel miras ve açık erişim, kullanılabilirlik ve bilgi erişim, kullanıcı araştırmaları, halk ve üniversite kütüphaneleri, bilgi güvenliği ve etik konuları altında sınıflandırılmıştır. Son olarak konuların dönemlere, tez türüne ve danışmanlara göre dağılımları değerlendirilmiştir.

$\mathrm{Bu}$ çalışmanın sonuçlarının tez danışmanları ve öğrencilere tez konusu belirleme aşamasında yardımcı olması beklenmektedir. Yoğun olarak çalışılan konular yerine az çalışılan veya hiç çalışılmayan güncel konulara öncelik verilmesinin bölümde çalışılan konuların çeşitlenmesi, daha dengeli bir dağılım sağlanması ve güncel gelişmelerin takip edilmesi açısından önemli olduğu düşünülmektedir. Çalışmadan elde edilen bulgular ve literatür karşılaştırması 1şığında bilgi paylaşımı, kültürel miras, açık erişim, dijitalleştirme, dijital insani bilimler, bilgi erişim, kullanılabilirlik, semantik web, arşiv yönetimi, e-devlet, elektronik veri, kişisel veri, bilgi güvenliği gibi konuların daha fazla çalışılması önerilmektedir.

Çalışmanın, Bilgi ve Belge Yönetimi bölümlerinde tamamlanan tezlerin metin analizi yöntemleri ile incelendiği ilk çalışma olması açısından, mevcut literatüre katkıda bulunması beklenmektedir. Gelecekteki çalışmalarda, Türkiye'deki tüm Bilgi ve Belge Yönetimi bölümleri tezlerinin analiz edildiği daha geniş kapsamlı değerlendirmeler yapılması, bölümlerin konusal açıdan benzerlikleri ve farklılıkları ile hangi konularda öne çıktıklarını ortaya koymak açısından fayda sağlayacaktır.

\section{Teşekkür}

Çalışmanın taslaklarını defalarca okuyarak önerilerini sunan Prof. Dr. Umut Al'a ve çalışmanın geliştirilmesinde önemli katkıları olan Doç. Dr. Tolga Çakmak'a çok teşekkür ederim.

\section{Kaynakça}

Al, U. ve Doğan, G. (2012). Hacettepe Üniversitesi Bilgi ve Belge Yönetimi Bölümü tezlerinin atıf analizi. Türk Kütüphaneciliği, 26(2), 349-369. Erişim adresi: http://www.tk.org.tr/index.php/TK/article/view/331

Al, U. ve Tonta, Y. (2004). Atıf analizi: Hacettepe Üniversitesi Kütüphanecilik Bölümü tezlerinde atıf yapılan kaynaklar. Bilgi Dünyast, 5(1), 19-47. Erişim adresi: https://www.bd.org.tr/index.php/bd/article/view/497

Alkan, G. (2014). Türkiye'de muhasebe alanında yapılan lisansüstü tez çalışmaları üzerine bir araştırma (1984-2012). Muhasebe ve Finansman Dergisi, 61, 41-52. doi: 10.25095/mufad.396448

Altınörs, G. (1983). Türkiye'de kütüphanecilik bilim dalı konusunda yapılmış olan doçentlik, doktora ve bilim uzmanlığı tezlerinde kullanılmış olan araştırma metodları. (Yüksek Lisans Tezi). Hacettepe Üniversitesi Sosyal Bilimler Enstitüsü, Ankara. Erişim adresi: http://bby.hacettepe.edu.tr/yayinlar/7.pdf

Bayram, Ö. ve Zan, B. U. (2014). Ankara Üniversitesi Dil ve Tarih-Coğrafya Fakültesi Bilgi ve Belge Yönetimi Bölümü'nde yürütülen lisansüstü tezlerin bibliyometrik analizi. N. Özel ve N. ErKoçoğlu (yay. haz.). Ankara Üniversitesi Bilgi ve Belge Yönetimi Bölümü 60.Yıl armağan kitabı içinde (s. 223-240). Ankara: Ankara Üniversitesi DTCF Bilgi ve Belge Yönetimi Bölümü. Erişim adresi: http://bilgibelge.humanity.ankara.edu.tr/files/2014/01/Ankara-\%C3\%9Cniversitesi-Bilgive-Belge-Y\%C3\%B6netimi-B\%C3\%B61\%C3\%BCm\%C3\%BC-60.y\%C4\%B11arma\%C4\%9Fan-kitab\%C4\%B1.pdf 
Benligiray, S. (2009). Türkiye'de insan kaynakları yönetimi alanında yapılan lisansüstü tezler ve bu tezlerde incelenen temaların analizi: 1983-2008 dönemi. Eskişehir Osmangazi Üniversitesi IİBF Dergisi, $\quad 4(1), \quad$ 167-197. Erişim adresi: https://arastirmax.com/en/system/files/dergiler/14926/makaleler/4/1/arastirmax-turkiyede-insankaynaklari-yonetimi-alaninda-yapilan-lisansustu-tezler-bu-tezlerde-incelenen-temalarin-analizi1983-2008-donemi.pdf

Binici, K. (2016). Kütüphane ve bilgi bilimi çalı̧̧malarında dönemsel konu analizi (Yayımlanmamış Doktora Tezi). İstanbul: İstanbul Üniversitesi Sosyal Bilimler Enstitüsü.

Blake, V. L. P. (1994). Research methods in library and information science dissertation, 1975-1989. Collection Management, 19(1-2), 1-42. doi: 10.1300/J105v19n01_01

Canata, F., Çapkın, Ç., Doğan, G., Sünger, B. ve Oynak, E. (2017). İstanbul Üniversitesi Bilgi ve Belge Yönetimi Bölümü lisansüstü tezlerinin atıf analizi. Türk Kütüphaneciliği, 31(1), 31-46. doi: 10.24146/tkd.2017.1

Çakın, İ. (2005). Cumhuriyet’ten günümüze bilgi profesyonellerinin eğitiminde başlıca yönelişler. Türk $\begin{array}{llll}\text { Kütüphaneciliği, } & \text { 19(1), 7-24. } & \text { Erişim }\end{array}$ http://www.tk.org.tr/index.php/TK/article/view/16/17

Çakın, İ. (2007). Kütüphanecilerin eğitiminden bilgi profesyonellerinin eğitimine: Hacettepe Üniversitesinde son yirmi yıl. S. Kurbanoğlu, Y. Tonta ve U. Al (yay. haz.). Değişen Dünyada Bilgi Yönetimi Sempozyumu, 24-26 Ekim 2007, Ankara, Bildiriler içinde (s. 19-23). Ankara: Hacettepe Üniversitesi Bilgi ve Belge Yönetimi Bölümü.

Çakın, İ. (2012). Bilgi profesyonellerinin eğitiminde 40 yıl: Hacettepe Üniversitesinin lisans programındaki değişiklikler. Türk Kütüphaneciliği, 26(2), 262-290. Erişim adresi: http://www.tk.org.tr/index.php/TK/article/view/317/309

Delen, D. ve Crossland, M. D. (2008). Seeding the survey and analysis of research literature with text mining. Expert Systems with Applications, 34(3), 1707-1720. doi: 10.1016/j.eswa.2007.01.035

Düzyol, G. (2011). Türkiye kütüphanecilik ve bilgibilim literatürünün entellektüel haritasının çıkarılması: bir yazar ortak atıf analizi çalışması. (Yüksek Lisans Tezi). Hacettepe Üniversitesi Sosyal Bilimler Enstitüsü, Ankara. Erişim adresi: http://www.openaccess.hacettepe.edu.tr:8080/xmlui/handle/11655/2910

Figuerola, C. G., García Marco, F. J. ve Pinto, M. (2017). Mapping the evolution of library and information science (1978-2014) using topic modeling on LISA. Scientometrics, 112(3), 15071535. doi: 10.1007/s11192-017-2432-9

Karaman, S. ve Bakırcı, F. (2010). Türkiye'de lisansüstü eğitim: sorunlar ve çözüm önerileri. Sosyal Bilimler Araştırmaları Dergisi, 2, 94-114. doi: 10.19129/sbad.171

Kayaoğlu, H. D. (2009). İstanbul Üniversitesi Bilgi ve Belge Yönetimi Bölümü’nde araştırma eğilimleri 1967-2008: lisansüstü tezlerinin içerik analizi. Türk Kütüphanciliği, 23(3), 535-562. Erişim adresi: http://www.tk.org.tr/index.php/TK/article/view/507

Kurbanoğlu, S. (1996). Kütüphanecilik ve bilgi bilim tezlerinde kullanılan araştırma yöntemleri: bir değerlendirme. Türk Kütüphaneciligi, 10(4), 350-359. Erişim adresi: http://bby.hacettepe.edu.tr/yayinlar/1418-2835-1-PB.pdf

Liew, W. T., Adhitya, A. ve Srinivasan, R. (2014). Sustainability trends in the process industries: A text mining-based analysis. Computers in Industry, 65(3), 393-400. doi: 10.1016/j.compind.2014.01.004

Lisansüstü Eğitim ve Öğretim Yönetmeliği. (20 Nisan 2016). Resmi Gazete (Sayı: 29690). Erişim adresi: https://www.mevzuat.gov.tr/mevzuat?MevzuatNo=21510\& MevzuatTur=7\&MevzuatTertip=5

Önal, İ. ve Dişli, M. (2017). Hacettepe'li profesörlerin bilgi yönetimi alanına bilimsel katkıları. Edebiyat Fakültesi Dergisi, $34(2), \quad 158-171 . \quad$ Erişim http://bby.hacettepe.edu.tr/yayinlar/onal\%20inci-meltem\%20disli.pdf 
Shu, F., Larivière, V., Mongeon, P., Julien, C. A. ve Piper, A. (2016). On the evolution of library and information science doctoral dissertation topics in North America (1960-2013). Journal of Education for Library and Information Science, 57(2), 131-142. doi: 10.12783/issn.2328$2967 / 57 / 2 / 5$

Song, Y., Zhu, L. ve Shu, F. (2020). On the evolution of library and information science doctoral dissertation topics in China. Journal of Librarianship and Information Science, online first, 1-9. doi: $10.1177 / 0961000620948573$

Türkiye Bilimler Akademisi (TÜBA). (2020). Türkçe bilim terimleri sözlüğü (sosyal bilimler). Ankara: TÜBA. Erişim adresi: http://www.tubaterim.gov.tr

Tonta, Y. ve Al, U. (2006). Scatter and obsolescence of journals cited in theses and dissertations of librarianship. Library \& Information Science Research, 28, 281-296. doi: 10.1016/j.lisr.2006.03.006

Uçak, N. Ö. (2004). User studies in Turkey: an evaluation of dissertations. Information Development, 20, 122-129. Erişim adresi: https://journals.sagepub.com /doi/abs/10.1177/0266666904045326?journalCode=idva

Yeap, C. K. ve Kaur, K. (2008). Citation study of library and information science dissertations for collection development. Malaysian Journal of Library and Information Science, 13(2), 29-47. Erişim adresi: https://www.researchgate.net/publication/237550223_Citation_study_of_library_and_informati on_science_dissertations_for_Collection_development

Yılmaz, B. (1997). Hacettepe Üniversitesi Edebiyat Fakültesi Kütüphanecilik Bölümü lisansüstü tezlerinin niceliksel ve konusal analizi: 1974-1997. Bülent Y1lmaz. (yay. haz.). Kütüphanecilik Bölümü 25. Yıla Armă̆an içinde (s. 191-198). Ankara: Hacettepe Üniversitesi.

Zin, T. H. E. (2017). Bibliometric analysis on MA thesis submitted to the Department of Library and Information Studies, Yadanabon University (2013-2017). Yadanabon University Research Journal, 8(1). Erişim adresi: http://hdl.handle.net/20.500.12678/0000000398

Zong, Q. J., Shen, H. Z., Yuan, Q. J., Hu, X.W., Hou, Z.P. ve Deng, S.G. (2013). Doctoral dissertations of Library and Information Science in China: A co-word analysis. Scientometrics, 94(2), 781799. doi: 10.1007/s11192-012-0799-1

\section{Summary}

Theses and dissertations are extremely important as comprehensive studies which examine the problems of a particular field in depth and offer solutions. Analyzing them conducted in a field and determining research trends is just as important. In this study, it was aimed to examine the theses and dissertations completed in the Department of Information Management at Hacettepe University, and to determine the trends of the theses and dissertations in the field. In this direction, 112 theses and dissertations completed between 2002 and 2020 in Hacettepe University Information Management Department were examined topically and answers were sought for the following research questions (RQ):

RQ1: Are there any periodically weakening and expanding topic in the theses and dissertations completed in the department?

RQ2: Is there a significant difference in the topics according to the thesis and dissertation type?

RQ3: How is the distribution of the supervisors in the topics?

Research hypotheses were determined as follows: H1: "specific topics were given more emphasis each period compared to other topics" ve H2: "supervisors focus on specific topics." 
In the study, in which the text mining method was applied, Knime, an open-source text analysis software, was used to analyze the data. Within the scope of the research, topic modeling was carried out with the use of the LDA and the word frequencies in the determined topics were analyzed using the n-gram. The theses and dissertations were divided into 8 different main topics through LDA. After the main topics were determined, the supervisors, year, type and topics of the theses and dissertations were transferred to the SPSS software. The relationships between the topics of them and their types, supervisors and periods were tested through SPSS. They in each main topic were subjected to n-gram analysis and the most studied sub-topics among these topics were determined, and a comprehensive label was assigned to the main topics by considering the sub-topics that are predominantly within the topics. They were classified under reading habits, electronic resources and bibliometric studies, records management, digital cultural heritage and open access, usability and information retrieval, user studies, public and university libraries, information security and ethics.

Considering the distribution of the topics according to the periods within the scope of the first research question (RQ1) of the study, it was observed that there is no significant difference in terms of topics matter according to the periods and the theses and dissertations were not completed at high rates on the same topics in each period. The hypothesis (H1) that certain topics are studied more than other topics in each period was not accepted, it was seen that there were issues that weaken and expand periodically.

In line with the second research question (RQ2), it was evaluated whether there was a topical difference according to the type of theses and dissertations. Although there is no significant difference in the distribution of topics according to the type of them, it has been determined that in master, which constitute the majority of the theses, a higher percentage of them are completed in the topic of digital cultural heritage and open access, while a higher percentage of them are completed in the doctorate in other topics.

According to the findings obtained within the scope of the research question (RQ3), the advisory of the theses and dissertations was mostly done by Bülent Y1lmaz, Yaşar Tonta and Özgür Külcü. The hypothesis of the research (H2) that supervisors focus on certain topics was accepted. Bülent Y1lmaz supervised the theses and dissertations on reading habits, Özgür Külcü records management, Umut Al electronic resources and bibliometric studies, and İnci Önal user studies. It is thought that this result will help students who will work on these topics in the selection of their supervisors. İrfan Çakın and Mehmet Emin Küçük are the supervisors who provide advisory services the most.

The results of this study are expected to assist the supervisors and students in determining the thesis topic. It has been determined that in theses and dissertations, there is a lot of work on bibliometric studies, records management, user studies, public and university libraries while the topics such as cultural heritage, open access, digitization, data management, personal data, sensitive data, information retrieval are less studied. It is believed that prioritizing current issues, which are studied less or not at all, rather than topics that are studied intensively, is important in terms of diversifying the topics studied in the department and following current developments. 